\title{
The Challenges of Framing Women Migrants' Rights in the European Union
}

Helen Schwenken

\section{(2) OpenEdition \\ 1 Journals}

Electronic version

URL: https://journals.openedition.org/remi/2357

DOI: $10.4000 /$ remi.2357

ISSN: $1777-5418$

Publisher

Université de Poitiers

Printed version

Date of publication: 29 May 2005

Number of pages: 177-194

ISBN: 2-911627-39-3

ISSN: 0765-0752

\section{Electronic reference}

Helen Schwenken, "The Challenges of Framing Women Migrants' Rights in the European Union", Revue européenne des migrations internationales [Online], vol. 21 - $n^{\circ} 1$ | 2005, Online since 08 September 2008, connection on 14 April 2022. URL: http://journals.openedition.org/remi/2357 ; DOI: https://doi.org/ 10.4000/remi.2357

This text was automatically generated on 14 April 2022.

() Université de Poitiers 


\title{
The Challenges of Framing Women Migrants' Rights in the European Union
}

\author{
Helen Schwenken
}

1 In all countries of the European Union domestic work performed by migrant women, often in an irregular legal status, is increasing. ${ }^{1}$ A considerable part of these workers faces poor living and exploitative working conditions (Anderson, 2000; Mate and Schepers, 2000; ILO, 2004) ${ }^{2}$. Migrant domestic workers themselves, support groups and advocacy organizations have developed multi-level strategies to improve these living and working conditions over the last decades. In this article I identify and analyze different ways and sometimes contradicting strategies of how the European network of migrant domestic workers, RESPECT, and other state and non-state actors mobilize and advocate for female migrant workers rights on the European Union

level $^{3}$. The case of migrant domestic workers specifically is a telling example of the challenges migrants, in general, face at the EU level to fight for extended rights.

Mobilizations of domestic workers on the national level were to a certain point successful. For example, in Great Britain, where after more than ten years of intensive campaigning, an official regularization procedure for abused migrant domestic workers was launched in 1998 (Ariyadasa, 1998b). The British campaign by migrant domestic workers' organizations, trade unions and advocacy groups, however, which is often regarded as a role model for other struggles, also reveals the ambivalences and limits of political success. Firstly, the regularization criteria for undocumented women working in precarious jobs were difficult to meet and secondly, the number of abuses did not decline after the policy changes were implemented (Anderson, 2004).

3 The British case leads to the main questions dealt with in this article: Does the European Union provide new opportunities for the demands of undocumented migrant workers? And in how far have the campaigns on the EU level been resonant and successful? 
The case study contributes to the current debate in social movement theory about the relation between the framing ${ }^{4}$ of a movement and the restrictions imposed by the specific political opportunity structures, and the question of the impact and success movements have (Marx Ferree, 2003; Giugni, McAdam and Tilly, 1999). Myra Marx Ferree criticizes that "resonance [...] is often seen as a sine qua non of a movement success" (Marx Ferree, 2003: 305). I support her objection as it is too simple to equate resonance with success, moreover not all movements head for unconditional resonance. I argue in this article that the resonance migrant domestic workers achieved in the European Union has been ambivalent: on the one hand it allowed structural access to EU policy makers but on the other it narrowed down political opportunities due to a fusion of migration policies with crime and security policies. Thus one should differentiate between the structural openness of a political opportunity structure and the one which relates to the political contents. Due to power relations and long-term political orientations, even good and consistent frames do not necessarily lead to a movement success. Nevertheless, I show that the European Union is relatively open to gender specific demands of undocumented migrants. Thus migrant women organizations and advocacy-networks face an advantage compared to maledominated or gender mixed organizations. But this more open opportunity structure for female migrants is for the same reasons ambivalent, as the specific problems arising from the lack of citizenship rights and restrictive immigration rules cannot be addressed adequately.

In the following section I will introduce the RESPECT-network, afterwards I address the question of how undocumented migrant workers develop individual and collective agency. Then I start the exploration of how the issue of domestic work came into the agenda of the European Union identifying the various strategies used. In the fourth section I describe the first strategy, that of fighting against trafficking in women which also includes - following a broad definition - severe exploitation in the domestic service sector. In the fifth section another strategy is presented, that of addressing the problems of migrant domestic workers as violations of women's rights. At the same time, a third strategy is used, the one of worker's rights, analyzed in the sixth section. In conclusion I discuss the results in the light of the social movement theory.

\section{The respect-network}

6 RESPECT is the abbreviation for "Rights, Equality, Solidarity, Power, Europe, Cooperation, Today". The network comprises self-organized migrant domestic workers' organizations, support organizations, trade unionists and academics from nine European countries as members. Among the members are the Filipino organization KASAPI from Greece, the Dominican women's organization VOMADE from Spain, the Philippine women's network BABAYLAN, DONNE NEL MUNDO from Italy, the Italian trade union FILCAMS-CGIL, the German RESPECT network with several attached organizations and others. The network campaigns for the rights of migrant women and some men - working in private households in EU countries. The European-wide RESPECT-network was founded in 1998 by the Filipino-British NGO Kalayaan and SOLIDAR, a Brussels based NGO which has close trade unions links on European Union level. With its constitution as a European network the organizations reacted to the 
need and the opportunities to raise the issue of the exploitation and legal status of migrant domestic workers at the EU level.

7 The member organizations from the UK, France, Spain, the Netherlands, Italy, Belgium, Ireland, Greece and Germany have been active in their local and national contexts long before. For example, Waling Waling ${ }^{5}$ and Kalayaan have been leading the above mentioned campaign for the rights of abused migrant domestic workers in the United Kingdom. Their division of labour has been a role model for the design of the Europeanwide network: Waling Waling is a self-help organisation of up to 5000 migrant domestic workers in London (Pearce, 2000). The workers largely come from the Philippines, but also from Sri Lanka, Malaysia, India, Peru and other countries. Kalayaan was founded as a campaigning organization, counselling migrant domestic workers, acting in the public sphere, working together with allies and negotiating with the government. The migrant women from Waling Waling are able to influence the policies of Kalayaan, but not the other way around, hence securing the autonomy of the migrants. The network is very well aware of the specific strength of the collaboration between self-organized migrants, advocacy organizations and academics, like that between Waling Waling and Kalayaan, as the following quote of one of the coordinators of the network shows: "For example the Transnational Conference at the end of November in Brussels, a room full of sixty women, all black women, all coming from all over the world. The people from the European Parliament, from the Commission - when they see that, you understand the strength of that network. Very unique, migrant women organizing themselves, and especially migrant domestic workers. When people ask... 'femmes de ménage', they just laugh" (Interview with one coordinator of the RESPECT-network, 28.11.2002).

Most of the network's European-wide activities have been financed by project funds for combating violence against women provided by the European Commission. In 2002 the funding was stopped and most European-wide activities like conferences, theatre workshops and campaigns could not be continued. The members keep on working on the local and national level and have a self-conception as part of a European-wide network.

\section{Developing agency among migrant domestic workers}

Undocumented migrant women face various barriers to organize themselves. The lack of a legal status makes them often hesitant to speak up publicly and demonstrate because of the fear of deportation. Private households in which women work are scattered in different city areas, most domestic workers have long working hours, more than one job or are live-ins ${ }^{6}$. This makes it difficult to exchange experiences, come together and find time for joint social and political activities. The Commission for Filipino Migrant Workers ${ }^{7}$, whose European branch is a member of the RESPECT-network, names very ambitious criteria for "empowered migrant workers": "They are able to develop and determine the strategies that will change and transform their living and working conditions. [...] They are organised as a sector. They know their rights and are able to campaign for them. They are able to link their own agenda to the realities of other migrants [...]. They have developed the skills to document their own situation" (CFMW, 2000: 2). Starting from the situation of undocumented migrant domestic workers, one can assume that it takes a lot of efforts to start organizing and mobilizing processes. 
10 Following the definition of the CFMW, the organizing process affects the individual level as well as the meso and macro level of organizing in groups and campaigning. I will mainly focus on political mobilizations by and for undocumented migrant domestic workers on the meso and macro level.

11 On the micro level Kyoko Shinozaki and Kimberly Chang/L. H. M. Ling demonstrate in how far migrant domestic workers manage to turn hierarchies upside down and develop certain trans-national, gendered or religious identities in order to cope with their situations and restructure power relations towards their employers and other domestic workers (Shinozaki, 2004; Chang and Ling, 2000: 38-40). For example, domestic workers might identify with the high social status of their employers and use it to draw a line between themselves and domestic workers working for employers with a lower social status. Not all of these strategies have empowering effects in the sense of the definition provided by the Commission of Filipino Migrant Workers. Coping with depriving living and working conditions on a micro level is on the one hand essential to keep up the spirits, but could also mean maintaining the status quo.

12 The RESPECT-network of migrant domestic workers follows a broader strategy. Individual empowerment is seen as the basic requirement for any further political and social engagement. "It's no use in a way to change laws [...] when you have basically women who don't make use of it, when the self esteem is completely down" (Interview with RESPECT/SOLIDAR, 28.11.2000). They try to build up social ties among the women and then transform the social networks into political ones and politicize every-day experiences, e.g. with the help of methods like forum theatre in the tradition of the theatre of the oppressed (RESPECT, 2001a; b). As most domestic workers have their day off on Sundays, members of migrant groups try to reach the women at places like parks or churches with services in foreign languages.

13 In the British case the organizational structure is, as already introduced, twofold: in the migrants' self-help group Waling-Waling only migrant domestic workers are active, while in the campaigning organization Kalayaan, supporters and domestic workers work together and the migrants could always veto policies of Kalayaan. As the following quotation shows, the existence of the self-organization was crucial to lower the wellknown dependence of migrants from charity organizations and to build the foundations for further involvement of the women: "The organisation of domestic workers themselves, they were the ones who gave the support to the new people running away. [...] Kalayaan would provide legal advice, explain what the situation was. And one from the domestic workers' organisation would come and take her, to find accommodation, look after finding a job, showed how to use the public transport, all of that. And they would also give them a loan that even if they were staying with other Indian or Filipino domestic workers that they would at least be able to contribute to the house, to the food whatsoever. Also to give them a bit of self-respect" (Interview with a co-founder of Kalayaan, 20.1.2002). The political strategies were developed on a dialogical basis between the two organisations. It worked in a comparable way on the European level.

14 After the experiences in Great Britain, Kalayaan and SOLIDAR took the initiative to enlarge the network and apply for funding from the European Commission. A comparative research, mostly carried out by Bridget Anderson (Anderson and Phizacklea, 1997; Anderson, 2000), in five European countries about living and working conditions of migrant domestic workers was the first step in finding partners 
throughout the EU. For the "Charter of rights of migrant domestic workers" (RESPECT, 2000a), which is the unifying document of the network, consultations with migrant domestic workers, au-pairs and advocacy groups in six European countries were held (CFMW and RESPECT, 2000: 2). The aim and self-conception was to include the experiences of the concerned migrants into the foundations of the network and its political activities. "In one of our seminars, it was the example of Ghandi, which is: 'what you do for us without us, is against us'. And I like it, it's completely empowerment. I mean, let them speak, first ask what they want" (Interview with RESPECT/SOLIDAR, 28.11.2000). The RESPECT network supports its members' campaigns and facilitates the sharing of experience and expertise in campaigning, organizing and lobbying. As the following analysis will show, these features of the network makes a difference in policy decisions compared to other organizations which act from the perspective of advocacy and human rights violations.

\section{Migrant domestic workers as "modern day slaves" and "victims"}

15 Some organizations regard exploitation in domestic service as a kind of trafficking in women or as modern day slavery (e.g. the report "Domestic Slavery" of the Council of Europe (2001)), indeed Kalayaan also used to work with the term "slavery" (Anderson, 1993; Kalayaan, 1995). Trafficking has been defined for a long time as a combination of coercion, deception, exploitation and prostitution. Hence migrant domestic workers did not fall into that category. But this has changed. Women's organizations recognized that sexual exploitation was not an issue in all cases of trafficking, and pointed to other forms of coercion and violence. After years of intense lobbying, the United Nations in 2000 passed a substantially widened definition of trafficking that included the abusive and exploitative situations in domestic work and mail-order-brides marriages ${ }^{8}$. The new definition of trafficking provided the basis for placing the exploitation of migrant domestic workers on the agenda of the European Union. The discussion about trafficking at the global level coincided with the development of policies against trafficking in the European Union in the mid-1990s'. Three main factors gave rise to the emergence of trafficking as a subject of discussion and the adoption of joint EU-policies on combating it: the existence of a feminist advocacy-network, a norm reactivation against trafficking and the opening of the political opportunity structure (Locher, 2002). First, the collaboration of women policy makers and feminist bureaucrats ("femocrats"), feminist scholars and women's movements protagonists in the EU can be called an "advocacy network" (Keck and Sikkink, 1998) or "velvet triangle" (Woodward, 2001). During the 1990s these actors put a lot of effort into placing the issue of trafficking on the political agenda. They bundled their specific abilities and knowledges: the "femocrats" and politicians had the relevant procedural knowledge within the EU-institutions, the gender experts and scientists brought in their technocratic and expert knowledge and last but not least the NGOs and women's movements activists had local experiences and could present testimonies of trafficked women which underlined the legitimacy and urgency of the issue (Locher, 2002: 54, 74). Secondly, the norm against trafficking in women has historic precursors. Since 1902 the international community has ratified international agreements against the trafficking of girls and women (Locher, 2002: 72ff; Rupp, 1997). Thus the norm was 
reactivated by the campaigns of the international women's movement on a global scale in the 1990s. The World Human Rights Conference in 1993 and the World Conference on Women in Beijing in 1995 have been important platforms for norm reactivation. The third factor that contributed to the successful agenda setting of trafficking has been changes in the general political opportunity structure and windows of opportunity. The transitions in Middle, Southeast and Eastern Europe and Central Asia brought about an increase in the phenomenon of trafficking. The 1996 Dutroux scandal in Belgium ${ }^{10}$ increased political pressure to combat the sexual exploitation and violence against girls and women. Further, institutional changes in the EU promoted the policy against trafficking. The Treaty of Maastricht in 1993 included the "third column" of justice and home affairs into the European Community policies giving the EU some backing to start initiatives. The Treaty of Amsterdam in 1997 named the fight against trafficking explicitly amongst its provisions and the competences of the European Parliament were extended. The EU summit in Tampere in 1999 strengthened the position of the European Commission regarding migration and asylum issues. These institutional changes resulted in a broader legitimacy at the European level to deal with justice and home affairs issues which formerly were solely in the competences of the national member states.

As explained, the multi-level system of the EU provided several structural points of entry in the 1990s to place the issue of trafficking on the political agenda. The different actors cooperated and succeeded in raising the issue of migrant domestic work, which had been integrated into the concept of trafficking. But, as I will explain later in more detail, the nature of the political opportunity structure only allowed activities within a narrow corridor.

Despite these enabling factors, the RESPECT-network decided in February 2001 to disassociate from the concept "domestic slavery" and from campaigns against trafficking in women (Schultz, 2001: 25). There have been various reasons for it. First, RESPECT identified differences in the experiences and needs of migrant domestic workers and trafficked women: "We found out, spending so much time on the ground, that most of the women, whether we like it or not, never heard of the word 'traffic', maybe some of them are smuggled but most of them arrive completely legally in Europe" (Interview with one coordinator of RESPECT, 28.11.2000). Their experiences influence their needs, as "you need a different approach, a whole different way of working. We shared with the domestic workers [...]; even they said they were in a different situation. And you need to work with women who are trafficked on a large scale; you need to be able to give a lot of time, support" (Interview with the co-founder of KALAYAAN, 20.1.2002). Besides the different experiences and needs, one coordinating member of the RESPECT-network describes secondly, the discrepancy of the related identity construction and thirdly, the political aims: "The Comite contre l'esclavage moderne, and somehow also Anti-Slavery International, which are not groups of self-organized women, which are not empowerment organizations, which are male dominated organizations, they decided to follow a completely different track - the one of trafficking. [...] They always emphasized [...] the worst cases of torture, rape and so which is a strategy, advertising on these most extreme cases of violence, then to bring it to court, then to show that that's modern slavery, that's trade in human beings and then to ask for these women for temporary residence permit on humanitarian ground" 
(Interview with one coordinating member of RESPECT, 28.11.2000). The dominant identity of the migrant women within the concept of trafficking is the one of a victim.

The RESPECT-network, in contrast, aims at overcoming the feeling of powerlessness among the migrants. The regularization of undocumented migrants as workers around which there is consensus amongst the members of the RESPECT-network - is thus not a policy put forward by most NGOs working against the trafficking in women. "For example the Comité contre l'esclavage moderne are not in the position of regularization of illegals for example, they don't want to touch that issue at all, they find it much too controversial" (Interview with a coordinator of RESPECT/SOLIDAR, 28.11.2000). It is further criticized that the driving force in combating the trafficking in women is not the well-being of women, but the state's interests in fighting irregular migration. Trafficking, therefore is intentionally equated with smuggling (Niesner, 2001; Sharma, 2003). The fight against trafficking is used to delegitimize and even destroy safer mechanisms of irregular migration.

The RESPECT-network further realized that the political opportunity structure of the frame of trafficking in women will not broaden in the long run but would rather be more and more restricted. Besides, the underlying identity construction did not fit to the networks' self-conception. The political background for the success of the "trafficking frame" lies in the discursive nexus of irregular migration and organized crime which had been promoted by national and European policy makers and which is mirrored in their policies. Some important regulations have been published by the European Commission to combat smuggling and trafficking with primarily repressive policies put highly on the agenda (EC, 2000a; EC, 2000b; EC, 2001; EC, 2003). Penelope Turnbull highlights the fusion of migration and crime policies in the EU as "key facilitators" which ensured, from her perspective, the successful introduction of policies against trafficking in women (Turnbull, 1999: 208-209).

\section{Migrant domestic workers as "women"}

In rejecting the frame of trafficking, the RESPECT-network did not give up arguing the gender-specific aspects of domestic worker's issues and continued the collaboration with the feminist velvet triangle, as the European Union's institutions seemed to be more open to women's rights than to migrant's rights : "The European Commission is relatively progressive on the rights of women, more progressive than they are on the rights of migrant workers, and we should try and use that" (B. Anderson, in: SOLIDAR and Kalayaan, 1996: 14). As a consequence of the experiences with the trafficking issue, the network went on accentuating rights, women's rights and migrant workers' rights. The rights based frames are regarded as capturing more of the real problems migrant domestic workers face and as opening the political opportunity structure which was narrowed down to restrictive policy responses prioritizing the combating of trafficking, smuggling and undocumented migration in general.

But it is not only due to strategic questions that the RESPECT-network focuses on gender issues, they stress that the migration experiences of women could have empowering effects: "More Filipino [are organized] because they speak English and, which is a specificity of their network, they are this generation of women which have migrated alone, which came to Europe, no husband, not following or bringing their children. And they have more this need of community, this approach of independence, 
like when you manage such a big step to leave your country as a women, they also seem to be more open to the issue of empowerment" (Interview with RESPECT/SOLIDAR, 28.11.2002). The identity construction of the powerful and proud - but nevertheless under certain conditions vulnerable - migrant woman is reflected in the images and publications of the network and the member organizations. Demanding the recognition of usually invisible domestic work as proper and well-paid work, also contributes to the approach of demanding respect and dignity.

The gender-specific approach of the network also creates preconditions for selfconsciousness, i.e combating violence against women in the households and in employer-employee relations. "It is very relevant to deal with it from the aspect of violence because than you immediately touch the aspect of empowerment" (Interview with RESPECT/SOLIDAR, 28.11.2000). To apply for money from the European Commission's DAPHNE-programme on violence against women was at first a strategic choice in order to fund EU-wide collaboration, but it turned out to be adequate in addressing the core issues of the network as well. It allowed addressing the difficult working conditions, physical and psychological violence female employers direct against their female employees and sexual harassment by male employers. The differences and similarities between domestic violence in intimate partnerships and that between employers and employees were discussed (RESPECT, 2000b). The main difference lies in the type of relationship. Violence between employers and employees is enhanced by the migration regulations that make undocumented women extremely dependent on the good-will of their employers. "Because of the particular nature of the employment relationship in the case of domestic work in private households, this immigration status must be completely independent of their employer" (RESPECT, SOLIDAR and KALAYAAN, 1998: 3). As the statement reveals, the issue of gendered violence directly leads to the questioning of certain migration regulations. Thus the gendered framing allows a frame extension to migration issues. Though the frame of trafficking has been extended to migration issues, it has done so in a solely restrictive way, the RESPECT-network meanwhile argues in the direction of granting more and better rights to - even undocumented - migrant women in order to protect them from domestic violence and other violence related to the migration process.

\section{Migrant domestic workers as "workers"}

23 The framing of migrant women's rights and issues is closely connected to the one of workers' rights. For example, a report of the European Parliament (EP, 2000) starts with discussing the consequences particular demographic developments have for women, EU citizens as well as legal residents and undocumented migrants. The report of the European Parliament took the rising need for domestic services and care for children and the elderly, and changing family structures as a starting point to think of new forms of care work and domestic services. The concern it highlights as most important was that the work so far is undeclared work and part of the informal economy. Thus the framing of the report was clear from the beginning on : that there was a growing problem within ageing societies and women's work. As a positive side-effect, from the perspective of the RESPECT-network, the work related approach of the report kept out the whole discussion about trafficking but allowed discussion about minimum labor standards and the social organization of reproductive labor ${ }^{11}$. The tasks domestic 
workers have to carry out are compared in the report with the ILO Convention C177 on Home Work (ILO, 1996) $)^{12}$ and the ILO International Standard Classifications of Occupations (ILO, 1990) ${ }^{13}$. Both provide narrow definitions, but are an expression of the intention to regard domestic work as proper work. Since a considerable part of private domestic service is done by (undocumented) migrant women, their problems are reflected in the report as well.

The example of the report of the European Parliament which has been adopted with a large majority of votes from nearly all political parties ${ }^{14}$, illustrates how different - in relation to the report of the Council of Europe (2001) - the perspectives on domestic work can be, even from institutions which reflect to a certain degree more mainstream positions than non-governmental organizations do.

The work related approach is, for some member organizations of the RESPECTnetwork, linked to a specific identity construction, the one of powerful, self-conscious migrants who know very well about their economic relevance for the sending countries: "Migrants in Europe are fully aware of the substantial contribution we as migrants make to the Philippines - to our families as well as to the economy. Migrant remittances for 1998 rose at US\$ 8 billion, approximately US\$ 2 billion of which were remitted from Europe" (CFMW, 2000: 5). The Commission of Filipino Migrant Workers regards the "sense of [the migrants'] own actual presence and numbers in a country or region" (CFMW, 2000: 2) as a political vehicle to demand better conditions in their country of origin and host country.

But this identity construction can also be challenged among domestic workers. While in the case of Filipinas, the identity as domestic workers is strengthened and they organize themselves as domestic workers, migrant domestic workers from Poland in Germany for instance do not want to be associated with the image of "domestic work" because they don't feel proud of it. They are much more hesitant to appear in public as domestic workers or be part of a domestic workers' organization. One reason is that their professional skills and degrees are not acknowledged in Germany and highly qualified women perform these unskilled jobs. Hence domestic migrant workers' groups in Germany refer to other identities and demand changes in the acknowledgement of skills and job opportunities for migrants in more skilled professions. De-skilling and occupational downward mobility are also phenomena a high percentage of the women coming from the Philippines and other "third world countries" struggle with. Many Filipinas are professionally trained as nurses or have college degrees, for example, in journalism, business administration or education. They too would prefer working in their professions (see Babaylan, 2001), and the transition to a low occupational status creates psychological discomfort (Lindio-McGovern, 2003: 527).

The reasons for the different identity-constructions between Filipinas and Polish women are from my perspective twofold: in the Polish case the de-skilling and migration are recent phenomena since the 1990s and the women are not willing to accept it. In the case of Filipinos, the Philippine state, since the 1970s, has instituted an explicit labour export policy (Rodríguez, 2002). Domestic workers are an integral part of this policy and even praised as national heroes. Moreover, organizations like the Filipino world-wide network Migrante International and CFMW had a clear working-class ideology. Hence, the aim is to conceive domestic work as "real work" which was considered more important than struggling for the unrealistic aim of overseas 
professional employment. In order to meet both perspectives, however, the international acknowledgement of professional training and educational degrees as well as domestic work as "real work" are therefore demands of the RESPECT-network (RESPECT, SOLIDAR and KALAYAAN, 1998: 3).

28 To refer to labor rights opens up another important aspect for successful mobilizing, access to trade unions as new potential allies. The relation between trade unions and undocumented migrants is not always easy (see e.g. Penninx and Roosblad, 2000), but in the British case, Kalayaan and Waling-Waling were supported by the Transport and General Workers' Union (TGUW). The union was very committed to the plight of the domestic workers and hundreds of migrant domestic workers became members of TGUW. The following statement of the Secretary General of the union illustrates the positive attitude towards the migrant women: "I bring the commitment of our Union, we pledge our continued support to your struggle and we say as Kennedy said, 'so long as you Overseas Domestic Workers are held in the bondage of degradation which you have experienced then none of our million members can claim to be free.' And they are with you in spirit, they are with you in your campaign, to continue the fight, to fight with you side by side until your freedom is as good as their freedom" (Morris, 1995: 5).

After the positive experiences with the trade union in Britain and after evaluating the difficulties related to working with the concept of combating trafficking in women, the RESPECT-network intensified the contacts to trade unions also in other countries and on the EU-level. "The trade union can be crucial in ensuring, firstly, that migrants know their rights, secondly in supporting migrants when those rights are abused and thirdly, in campaigning for those rights not yet given: for domestic work in the private household to be categorised as 'proper' work. For full and non-discriminatory employment rights and social protection" (Pearce, 2000: 4; see also: Ariyadasa, 1998a: 4).

Thus, trade unions might be the ideal partners for the RESPECT-network, but there are also limitations. Female and reproductive labor have never been prioritized by unions and in some countries, trade unions' rank and file are extremely hostile towards irregular migrants. Since the trade union leaders are often more open-minded, the RESPECT-networks follows a top-down approach: "We're approaching from the Women's Commission, then we have Migrant's Commission. But what we found out, there is some limitation in working bottom-up, so we're now working a lot from the top-bottom" (Interview SOLIDAR/RESPECT, 28.11.2000). The current debates in the trade unions about declining membership and innovative ways of recruiting workers in the informal sector are regarded as a window of opportunity to put the concerns of undocumented migrants on the agenda of organized labor.

31 To sum up, the labor related framing allows issues of migration policies like the admission policies of the EU to be addressed. This could not have been achieved with the frame of trafficking. Labor related framing also means that trade unions could be a new potential ally in order to widen the political opportunity structure.

\section{Conclusion}

32 In this article I dealt with the RESPECT-network itself and its political mobilizations to improve the living and working conditions of migrant domestic workers in the EU. 
The network addresses the different dimensions of problems domestic workers face, like exploitation, isolation and sexual harrassement. The political approach of the network is to combine individual and collective empowerment and policy interventions at different political levels. The overall aim can be reached by the unique structure of the network, in which migrant domestic workers collaborate with NGOs and researchers, and the reflection of racial and class hierarchies within the network.

The three different political strategies I identified are all dealing with domestic work and bring forward suggestions of how to stop exploitation. But, there are more differences than communalities. The conceptions of the migrants that underlie these strategies range from regarding them as helpless victims to self-conscious agents. Hence, the approaches are either state-centered or migrant centered. The approach of combating trafficking in women tends to, due to its closeness to anti-immigration policies, externalize the problems (e.g. by fighting illegal migration, deportation of the victims of trafficking after their testimony at court), while the other approaches aim at dealing with the problems within the receiving countries (e.g. regulation of the domestic service sector, human rights).

5 The RESPECT-network tries to make use of new opportunities developed at the European Union level compared to the national level. It has been shown that the EU is not a homogenous block, but that different institutions act differently. For example, in the European Commission the Directorate General on Justice and Home Affairs pushes more security-driven policies against illegal migration than the Directorate General on Labour and Social issues which promotes more women's and labour rights and the regulation of the widely informalized domestic service sector.

One of the enhancing factors of bringing the issue of migrant domestic workers forward in the European Union is the existence of the feminist velvet triangle. The velvet triangle not only allows women's issues to be placed on the agenda of the European Union but it contributes to decision-making and policy implementation as its members originate from different backgrounds and institutional contexts. The velvet triangle provides structural access on various levels, but regarding the more contested migration related demands it only offers limited resonance. One reason lies in the still dominating national competence for most of the migration issues, especially regularisation campaigns, and in the hegemonic political perspective of relating irregular migration to organized crime.

In the light of the current debate in social movement theory, the limits of active framing by movements are very clear. The most consistent and legitimate frame cannot gain enough resonance if the power relations shape the dominant discourses in another way. Reflecting the political power relations, the RESPECT-network disassociated from a currently very resonant frame. Thus, the case provides evidence that social movements not always prioritize resonance but decide applying less resonant but more strategically appropriate frames. The reasons are twofold for giving priority to one frame over the other : long-term considerations and political principles on one hand, but also the intervention of migrant women themselves who rejected the frame of trafficking. The example analysed in this text points to the importance of coalition building in the advocacy network composed of different actors and also actively involving undocumented migrants. 


\section{BIBLIOGRAPHY}

ANDERSON Bridget (1993) Britain's Secret Slaves: an Investigation into the Plight of Overseas Domestic Workers, London, Anti-Slavery International, Kalayaan.

ANDERSON Bridget (2000) Doing the Dirty Work. The Global Politics of Domestic Labour, London/New York, Zed Books.

ANDERSON Bridget (2004) The Devil is in the Detail: Lessons to be Drawn from the UK's recent Exercise in Regularising Undocumented Workers, in Michele Le Voy, Nele Verbruggen and Johan Wets Eds., Undocumented Migrant Workers in Europe, Brussels/Leuven, Platform for International Cooperation on Undocumented Migrants, Katholieke Universiteit Leuven, pp. 89-101.

ANDERSON Bridget and PHIZACKLEA Annie (1997) Migrant Domestic Workers: A European Perspective. Report to DG V of the European Commission, Brussels, European Commission.

ARIYADASA Kumi (Co-ordinator, Kalayaan) (1998a) Kalayaan and the Trade Unions. Working together to protect workers' rights, Kalayaan! Justice for overseas domestic workers, 5 (Spring), p. 4.

ARIYADASA Kumi (Co-ordinator, Kalayaan) (1998b) Working with the Government, Kalayaan! Justice for overseas domestic workers, 5 (spring), pp. 1-2.

BABAYLAN Philippine Women's Network in Europe (2001) Conference Declaration. Rising above poverty - Towards forward-looking strategies for the (economic) empowerment of Filipinas in Europe. Rome, 18-21 October 2001, http://home.datacomm.ch/balikatan/8/8.htm (16.1.2005).

CFMW Commission for Filipino Migrant Workers (2000) Perspectives on Migrant Empowerment. Filipino Migrant Community in Europe. Conference, 28-30 march 2000, Chiang Mai, Thailand, Amsterdam.

CFMW Commission for Filipino Migrant Workers and RESPECT European Network of Migrant Domestic Workers (2000) Charter of Rights for Migrant Domestic Workers. A Case Study in Migrant Capacity-Building \& Migrant Rights Advocacy. Regional Workshop on the Rights of Migrant Workers: Capacity Building in Monitoring Violations and Accessing Remedies, Ciang Mai, Thailand, April 1-3, 2000, Amsterdam, Brussels, London, CFMW, RESPECT, Kalayaan.

CHANG Kimberly A. and LING L.H.M. (2000) Globalization and its intimate other : Filipina domestic workers in Hong Kong, in Marianne H. Marchand and Anne Sisson Runyan Eds., Gender and Global Restructuring. Sightings, sites and resistances, London, New York, Routledge, pp. 27-43.

COUNCIL OF EUROPE Committee on Equal Opportunities for Women and Men (2001) Domestic slavery. Rapporteur: Mr Connor, Ireland, EPP/CD. Draft report. AS/Ega (2001) 2. 3 January 2001, Strasbourg.

EC Commission of the European Communities (2000a) Communication from the Commission to the Council and the European Parliament Combating trafficking in human beings and combating the sexual exploitation of children and child pornography. Proposal for a Council Framework Decisio. Brussels, 21.12.2000, COM(2000) 854 final, Brussels.

EC Commission of the European Communities (2000b) Communication from the Commission to the Council and the European Parliament on a Community Immigration Policy. Brussels, 22.11.2000, COM (2000) 757 final, Brussels.

EC Commission of the European Communities (2001) Mitteilung der Kommission an den Rat und das Europäische Parlament über eine Gemeinsame Politik auf dem Gebiet der Illegalen Einwanderung. Brüssel, den 15.11.2001, KOM(2001) 672 endgültig, Brüssel. 
EC Commission of the European Communities (2003) Communication from the Commission to the European Parliament and the Council in view of the European Council of Thessaloniki on the Development of a Common Policy on Illegal Immigration, Smuggling and Trafficking of Human Beings, External Borders and the Return of Illegal Residents. Brussels, 3.6.2003. COM (2003) 323 final, Brussels.

EP European Parliament (2000) Report on regulating domestic help in the informal sector (2000/2021(INI)). Committee on Women's Rights and Equal Opportunities. Rapporteur: Miet Smet. FINAL a5-0301/2000. EN, Brussels.

GAMSON William A. and MEYER David S. (1996) Framing political opportunity, in Doug McAdam, John D. McCarthy and Mayer N. Zald Eds., Comparative Perspectives on Social Movements. Political Opportunities, Mobilizing Structures and Cultural Framings, Cambridge, Cambridge University Press, pp. 275-290.

ILO International Labour Organisation (1990) International Standard Classification of Occupations. Sub-group 9131, ISCO-88, Geneva, ILO.

ILO International Labour Organisation (1996) C177 Home Work Convention, Geneva, ILO.

ILO International Labour Organisation (2004) Report VI. Towards a fair deal for Migrant Workers in the global economy. International Labour Conference. 92nd Session 2004. Sixth item on the agenda, Geneva, ILO.

KALAYAAN (1995) Justice for Overseas Domestic Workers. 1995 Slavery Still Alive. Conference Papers, London, Kalayaan.

KECK Margaret E. and SIKKINK Kathryn (1998) Activists beyond borders: advocacy networks in international politics, Ithaca/New York, Cornell University.

LINDIO-McGOVERN Ligaya (2003) Labor Export in the Context of Globalization. The Experience of Filipino Domestic Workers in Rome, International Sociology, 18 (3), pp. 513-534.

LOCHER Birgit (2002) Internationale Normen und regionaler Policy-Wandel: Frauenhandel in der Europäischen Union, WeltTrends, (36), pp. 59-79.

MARX FERREE Myra (2003) Resonance and Radicalism: Feminist Framing in the Abortion Debates of the United States and Germany, American Journal of Sociology, 109 (2), pp. 304-344.

MATE Kwabena and SCHEPERS Marleen (2000) Invisible Servitude. An In-Depth Study on Domestic Workers in the World. Description and Recommendations for Global Action. Social Alert, Series: "Research on Human Rights", Brussels.

MORRIS Bill (1995) Statement, in Kalayaan Eds., Documentation of the Conference "Slavery Still Alive", 1995, London, Kalayaan, pp. 4-5.

NIESNER Elvira (2001) Frauenhandel zwischen Tabuisierung, Dramatisierung und Instrumentalisierung - Herausforderungen für die feministische Forschung und Praxis durch ein internationales und tagespolitisch aktuelles Problem, in Ursula Hornung, Sedef Gümen and Sabine Weilandt Éds., Zwischen Emanzipationsvision und Gesellschaftskritik. (Re)Konstruktionen der Geschlechterforschung, Münster, Westfälisches Dampfboot, pp. 239-266.

PEARCE Natasha (2000) How can migrants organise themselves? Paper presented at the Rosa Luxemburg Conference: Future Conditions of Work. Trade Unions - Migrants - Women. November 25/26 2000, Hamburg, unpublished paper.

RESPECT European Network of Migrant Domestic Workers (2000a) Charter of Rights for Migrant Domestic Workers, London/Brüssel. 
RESPECT European Network of Migrant Domestic Workers (2000b) The Home: Haven or hell? Combating violence in private households. RESPECT Transnational Conference. 8th November 2000. International Trade Union House, Brussels, Belgium, Brussels.

RESPECT European Network of Migrant Domestic Workers (2001a) Migrant Domestic Workers: Acting Together. RESPECT: Reports from the EU Workshops 2001, London, RESPECT.

RESPECT European Network of Migrant Domestic Workers (2001b) Migrant Domestic Workers: Acting Together. RESPECT: Transferable Model for Using Forum Theatre, London, RESPECT.

RESPECT European Network of Migrant Domestic Workers, SOLIDAR and KALAYAAN (1998) Taking Liberties, Brussels, Solidar.

RODRÍGUEZ Robyn Magalit (2002) Migrant Heroes: Nationalism, Citizenship and the Politics of Filipino Migrant Labor, Citizenship Studies, 6 (3), pp. 341-356.

RUPP Leila (1997) Worlds of Women. International Women's Organizations 1888-1945, Princeton, Princeton University Press.

SCHULTZ Susanne (2001) Domestic Slavery oder Green Card? Feministische Strategien zu bezahlter Hausarbeit, Blätter des Informationszentrums Dritte Welt, (257), pp. 23-26.

SHARMA Nandita (2003) Travel Agency: A Critique of Anti-Trafficking Campaigns, Refuge. Canada's Periodical on Refugees, 21 (3), pp. 53-65.

SHINOZAKI Kyoko (2004) Making Sense of Contradictions: Examining Negotiation Strategies of "Contradictory Class Mobility" in Filipina/Filipino Domestic Workers in Germany, in Thomas Geisen (dir), Arbeitsmigration. WanderarbeiterInnen auf dem Weltmarkt für Arbeitskräfte, Frankfurt a.M., London, IKO-Verlag, in press.

SNOW David A. and BENFORD Robert D. (1992) Master Frames and Cycles of Protest, in Aldon D. Morris and Carol McClurg Mueller Eds., Frontiers in Social Movement Theory, New Haven/London, Yale University Press, pp. 133-155.

SOLIDAR and KALAYAAN (1996) Overseas Domestic Workers. Report after the Round Table in Brussels on 5th-6th June 1996, Brussels/London, SOLIDAR, Kalayaan.

TURNBULL Penelope (1999) The Fusion of Immigration and Crime in the European Union: Problems of Cooperation and the Fight against Trafficking in Women, in Phil Williams Ed., Illegal Immigration and Commercial Sex. The New Slave Trade, London, Portland/Or, Frank Cass, pp. 189-231.

UN United Nations (2000) Protocol to Prevent, Suppress and Punish Trafficking in Persons, especially Women and Children, Supplementing the United Nations Convention against Transnational Organized Crime, Geneva, UN.

WOODWARD Alison (2001) Die McDonaldisierung der internationalen Frauenbewegung: Negative Aspekte guter Praktiken, Zeitschrift für Frauenforschung und Geschlechterstudien, 19 (1+2), pp. 29-44.

\section{NOTES}

1. This article has been written while staying as a Guest Scholar at the Center for Comparative Immigration Studies (CCIS) at the University of California San Diego with a scholarship from the German Academic Exchange Service (DAAD). I would like to thank both institutions for giving me the opportunity to profit from the inspiring academic surrounding at CCIS. I am grateful for comments and suggestions by Kristen Hill Maher, Stefan Alscher, Francesca Mazzolari, Robyn 
Rodríguez, Takeyuki (Gaku) Tsuda and the editors of the issue, Christine Catarino and Mirjana Morokvasic-Müller.

2. Many migrant domestic workers encounter the following problems: working long hours, especially "live-ins" who may be required to be "on call" 24 hours a day; low wages, sometimes undocumented migrant workers receive no payment at all when the employer exploits their vulnerable situation; violence and sexual harassment; they are often requested to do additional work for employers' friends or relatives with no additional payment; care-takers are often being expected to do additional domestic shores; the relationship to the (female) employer is highly personalized (RESPECT, SOLIDAR and Kalayaan, 1998: 5; Anderson, 2000; Anderson, 1993; EP, 2000).

3. The case study is part of my doctoral thesis on political mobilization in the policy field of irregular migration in the European Union. The data contains documentary analysis and forty expert interviews with relevant actors of whom most are active in migrant groups and NGOs. Most of the data has been collected between 2000 and 2002. The documents, mainly grey material and publications of social movement organizations and policy documents of EU institutions, originate from the early 1990ies to 2004. Further more, participatory observation of meetings and conferences of the RESPECT-network and related events has been carried out.

4. The concept of framing in social movement theory deals with reality construction and the interaction between movements and opportunities (Gamson and Meyer, 1996: 276). The concept assumes that one has to choose the right words and strategy in order to place one's interests successfully in the public. The constitution of problems as problems is a first step: "Activists employ collective action frames to punctuate or single out some existing social condition or aspect of life and define it as unjust, intolerable, and deserving of corrective action" (Snow and Benford, 1992: 137). Further more a frame allows to weave together threads of information or aspects which have been discussed separately before, which means to interconnect them meaningfully. A third important aspect of frames is their potential to mobilise. As frames are "flexible modes of interpretation", they are "inclusive systems that allow for extensive ideational amplification and extension" (Snow and Benford, 1992: 137).

5. Waling-Waling is " a Filipino word, is a flower. It grows in the very cold part of the mountains. They describe themselves as a Waling-Waling because they say, that they always hide to the authorities because they become undocumented when they left their employer. [...] It's very seldom you see it. It was in 1998. They said 'oh we gonna be legal all', and they said we're not a Waling-Waling any more, we will not be undocumented. And what they did is to change the name to United Worker's Association" (Interview with Kalayaan/United Worker's Association, 20.1.2002).

6. "Live-in" means living in the house of the employer and working only for his/her family. Working "live-outs" usually means working for several employers and living in a separate residence. As live-outs feel more independent and usually earn more, most live-ins try to move out after some time (Anderson, 2000: 28, 39-47).

7. In Europe the Commission for Filipino Migrant Workers (CFMW) started working in 1979 in London and Rome, since then they have been regularly organizing European conferences and run an office in Amsterdam. CFMW works "in partnership with the Filipino migrant community and aims to develop migrant empowerment and capacity building through self-organization, education and campaigns for migrant rights and welfare and for solidarity with migrants of other nationalities against racism" (www.cfmw.org, date of access 17 November 2004).

8. The exact definition is as follows: "Trafficking in persons' shall mean the recruitment, transportation, transfer, harboring or receipt of persons, by means of the threat or use of force or other forms of coercion, of abduction, of fraud, of deception, of the abuse of power or of a position of vulnerability or of the giving or receiving of payments or benefits to achieve the consent of a person having control over another person, for the purpose of exploitation. Exploitation shall include, at a minimum, the exploitation of the prostitution of others or other 
forms of sexual exploitation, forced labor or services, slavery or practices similar to slavery, servitude or the removal of organs" (UN, 2000: 2).

9. It started with a high-ranking conference in 1996, organized by the committed Swedish Commissioner for Justice and Home Affairs, Anita Gradin. A communication by the Commission and the announcement of the action-programs STOP (STOP I, 1997-2000, and STOP II, 2001-2002, aim at preventing and combating trade in human beings and the sexual exploitation of children) and DAPHNE $(1997,2000)$ followed. The European Parliament passed in 2000 a report which was drafted by the women's rights activist and Member of the European Parliament, Patsy Sörensen. In the same year, the European Commission presented an integrated strategy of how to fight trafficking in women as well as a Council Framework Decision. On the international women's day in 2001, the Commission organized an information day on trafficking. Combating trafficking was also an issue at the negotiations with the candidate states and the commitment of fighting it was made one of the entry cards into the EU.

10. In 1995 and 1996, Marc Dutroux, his wife and an accomplice abducted six girls in Belgium; two were murdered, two starved to death. Up to 300000 Belgians denounced the failure of the justice system and problems with the investigations at so called "white marches". In 1998, Dutroux escaped and the ministers of Justice and Interior had to resign. In June 2004, Dutroux was finally convicted. It remained unclear if he was part of a pedophile network.

11. It contains the following work related demands: labour related immigration status, regulation of the market for paid domestic work, recognising domestic work as proper work, working contracts, social protection, minimum wage, organisation in trade union, acknowledgement of qualifications, access to training courses, education of employers to respect the employee's rights and dignity.

12. So far only two countries (Finland, Ireland) ratified this Convention.

13. The ILO uses the following job description: "Domestic Helpers and Cleaners sweep, vacuum clean, wash and polish, take care of the household linen, purchase household supplies, prepare food, serve meals and perform various other duties" (ILO, 1990).

14. Voting in the Committee, see: Minutes of the meeting of 9/10 October 2000, Brussels, European Parliament, Committee on Women's Rights and Equal Opportunities, PE/XVI/PV14: 4; voting of the EP, see: Smet report A5-0301/2000, 30 November 2000, Official Journal of the European Communities, 13.8.2001, C 228/113-118.

\section{ABSTRACTS}

In all countries of the European Union domestic work performed by migrant women, often in an irregular legal status, is increasing. Many workers face poor living and exploitative working conditions. Over the last decades, migrant domestic workers and advocacy organizations have developed multi-level strategies to improve those living and working conditions. In the contribution different and sometimes contradicting strategies of how a European network of migrant domestic workers and other actors mobilize will be identified and analyzed. It will be argued that the resonance the network achieved in the European Union was ambivalent and encompassed unintended consequences: On the one hand it allowed structural access to EU policy makers but on the other hand it narrowed down the political opportunities due to a fusion of migration policies and security policies. 
Les enjeux des droits des femmes migrantes dans l'Union Européenne.

On observe dans tous les pays de l'Union Européenne un accroissement du travail des femmes migrantes effectué de plus en plus dans des conditions illégales. Les travailleuses migrantes sont nombreuses à faire face à des conditions de vie précaires et à l'exploitation dans leur travail. C'est pourquoi, tout au long des dernières décennies, les femmes migrantes employées dans un travail domestique et les associations de défense ont développé des stratégies pour améliorer les conditions de vie et de travail. Cet article identifie et analyse différentes stratégies de mobilisation, parfois contradictoires, développées par un réseau européen de travailleuses domestiques migrantes et par d'autres acteurs. On s'interrogera sur les résonances de ce réseau au sein de l'Union européenne: ont-elles été ambivalentes? Ont-elles donné lieu à des conséquences inattendues? Il semblerait que d'une part, elles aient permis d'alerter les instances européennes mais que d'autre part, elles aient réduit les possibilités d'entrée en raison d'une fusion des politiques migratoires et sécuritaires.

\section{La cuestión de los derechos de las mujeres inmigrantes en la Unión Europea.}

Podemos observar en todos los países de la Unión Europea el incremento del empleo de mujeres inmigrantes, cada vez más bajo condiciones de ilegalidad. Numerosas trabajadoras inmigrantes afrontan condiciones de vida precarias y la explotación en el trabajo. Es la razón por la cual, a lo largo de las últimas décadas, las mujeres inmigrantes empleadas en tareas domésticas y las asociaciones de defensa han desarrollado estrategias para mejorar las condiciones de vida y de trabajo. Este artículo identifica y analiza diferentes estrategias de movilización, en ocasiones contradictorias, desarrolladas por una red europea de empleadas domésticas inmigrantes y por otros actores. Nos cuestionaremos sobre las resonancias de esta red

\section{INDEX}

Mots-clés: droits, femmes, droit du travail, conditions de vie, personnel de service Geographical index: Union Européenne

\section{AUTHOR}

\section{HELEN SCHWENKEN}

Social scientist, research and teaching associate at the University of Kassel, Dept. of Social Sciences, Nora-Platiel-Str. 1, D-34127 Kassel, Germany and guest scholar at the Center for Comparative Immigration Studies at the University of California San Diego (2004-2005). Contact: Helena.Schwenken@uni-kassel.de 